\title{
CORRIGENDUM
}

\section{The decoupling of and affluence discharge under spatial correlation: do richer communities discharge more waste? - CORRIGENDUM}

\author{
DAISUKE ICHINOSE, MASASHI YAMAMOTO and \\ YUICHIRO YOSHIDA
}

doi:10.1017/S1355770X14000370, published online by Cambridge University Press, 28 May 2014.

There was an error made in the title of the above published article. The title should have appeared as 'The decoupling of affluence and waste discharge under spatial correlation: Do richer communities discharge more waste?' This error has now been rectified in the original article.

\section{Reference}

Ichinose, D., M. Yamamoto and Y. Yoshida, The decoupling of affluence and waste discharge under spatial correlation: Do richer communities discharge more waste?. Environment and Development Economics. Published online $28^{\text {th }}$ May 2014, doi:10.1017/S1355770X14000370. 